\title{
23 \\ Five decades of Lapita archaeology: A personal retrospective
}

\author{
Patrick V. Kirch
}

\begin{abstract}
My engagement with the archaeology of Lapita having now extended over exactly five decades, I offer the following reflections on how the field has changed and advanced over this period, in terms of the questions being posed, the field and lab methods applied, and the resulting interpretations. This is not intended as a comprehensive or even balanced overview, but rather as the personal perspective of one researcher. I conclude with a brief assessment of the current stateof-play and a few suggestions for where the field might develop in coming years.
\end{abstract}

\section{Introduction}

I first became aware of Lapita in the late spring of 1968 when I told Roger Green, then on the staff of Honolulu's Bishop Museum (where as a high school student I had begun volunteering in the archaeology program), that I would be accompanying the museum's zoologist Yoshio Kondo on an expedition to the Loyalty Islands during the coming summer. Green told me that I should keep my eyes open for any archaeological sites with potsherds marked with a distinctive kind of decoration that he referred to as 'dentate stamping'. Green believed that Lapita would prove crucial to unravelling the immediate origins of the Polynesians, as he had indeed alluded to in a then recently published article (Green 1967:234-235). Following up on our conversation, I consulted Gifford and Shutler's Archaeological excavations in New Caledonia (1956), acquainting myself with the pottery they had uncovered at the eponymous site of Lapita. Although dentatestamped pottery had been found some decades earlier, both by Father Otto Meyer at Watom Island and by W.C. McKern in Tonga (Kirch 1997:6), it was Gifford's work at Site 13 at Koné, and most especially his recognition that the Site 13 pottery was closely related to the earlier Watom and Tonga finds, that initiated the modern period of Lapita archaeology. Gifford is thus the first of the trio of Lapita archaeology pioneers whom I call 'The Three G's': Edward Gifford, Jack Golson and Roger Green.

\section{Lapita: From culture history to cultural complex}

Although I did not find any Lapita pottery during my zoological fieldwork on Lifou, Maré and Ouvea islands during the summer of 1968, my interest in the archaeology of the southwestern Pacific continued to deepen as I studied for my anthropology degree at the University of Pennsylvania. I read Jack Golson's report on excavations in New Caledonia, Fiji and Western 
Polynesia, in which he boldly asserted that the dentate-stamped and related pottery finds represented 'some early community of culture linking New Caledonia, Tonga, and Samoa' (1961:176). Golson's article on Lapita from the 1969 Sigatoka conference (Golson 1971) made the case for a 'Lapitoid' ceramic series linking the early dentate-stamped assemblages with the later plainware assemblages of Samoa and Tonga in unbroken sequences. In this, Golson applied the 'ceramic series' concept of Irving Rouse (with whom I would soon study at Yale), which merged the then widely used culture-historical categories of archaeological 'horizon' and 'tradition'. In short, the questions being asked about Lapita at the end of the 1960s were still largely framed within the 'culture-historical' paradigm that dominated archaeology at the timequestions of time and space, and of cultural relationships as understood through material culture, especially the distinctive pottery.

By 1970, Roger Green was convinced that tracing the immediate origins of the Polynesians was going to require new fieldwork in Eastern Melanesia, specifically in the south-eastern Solomon Islands, at the time virtually terra incognita from an archaeological perspective. Linguistic work by Andy Pawley and others had pointed to the languages of the south-east Solomons as closely related to Polynesian, leading Green to hypothesise that sites with Lapita pottery would be found there. Together with ethnobotanist Douglas Yen, Green submitted a research proposal to the US National Science Foundation for a Southeast Solomon Islands Culture History Programme (SSICHP), to be coordinated by the Bishop Museum. The SSICHP was conceived as both multi-disciplinary and multi-institutional, putting linguists, ethnographers and ethnobotanists in the field together with archaeologists in a series of subprojects from 1970 to 1972 (Green and Cresswell 1976). Geographically, the SSICHP spanned the islands from Makira (then known as San Cristobal) eastwards to the Reefs-Santa Cruz group, as well as the Polynesian Outlier of Anuta (the success of the SSICHP would later serve as a model for the Lapita Homeland Project in 1985).

In his initial 1970 fieldwork in the Reef Islands and nearby Nendö, Green hit Lapita paydirt, especially with the Nenumbo (RL-2), Ngamanie (RL-6) and Nanggu (SZ-8) sites, all of which were rich not only in dentate-stamped pottery but also in other kinds of portable artefacts (including obsidian and chert) and in shell and bone faunal remains (Green 1976). More importantly, Green applied innovative new field methods, including a sampling strategy that began by mapping the surface distribution of pottery and then using the resulting density maps to guide a 'stratified, systematic unaligned' approach to excavation (Green 1976: Table 18, Figure 75). This approach allowed Green to move from looking at Lapita just as a kind of pottery, to aspects of the sites and settlements that contained the ceramics, such as their size and spatial organisation. His excavation and subsequent analysis of the Nenumbo site, in particular, set a standard for excavation and analysis of the internal structure of a Lapita hamlet that has only been matched at a few other sites (Sheppard and Green 1991). Drawing upon his training in geology, Green also initiated some of the first geochemical analyses of the sources of obsidian, chert and ceramic temper, thus opening the door to the vast topic of Lapita long-distance trade or exchange. Although the available methods at this time were crude by comparison with contemporary techniques, they were sufficient to reveal, for example, the importation of obsidian in the Reefs-Santa Cruz Islands from sources in the Bismarck Archipelago, a major breakthrough in our understanding (Ambrose and Green 1972).

My own involvement in the SSICHP came in the fall of 1971, when Paul Rosendahl and I accompanied Doug Yen to the Polynesian Outlier of Anuta, where we spent two months in fieldwork (see Kirch 2015:49-70 for an account of that expedition). On the voyage out to Anuta, the Belama stopped in the Reef Islands, where the three of us visited the Nenumbo site excavated by Green the previous year. The local villagers showed us where they had dug with Green, the ground still littered with dentate-stamped potsherds brought to the surface by yam 
gardening. On Anuta, Paul and I excavated the well-stratified An-6 site underlying the current village of Polynesian-speaking Anutans. In the deepest layer, radiocarbon-dated to between 3115 to $2715 \mathrm{BP}$, we recovered reddish, calcareous-sand tempered ceramics, mostly plainware, along with shell adzes, fishhooks and other portable artefacts (Kirch and Rosendahl 1973). The pottery seemed to be related to Lapita, and our radiocarbon dates overlapped with those Green had obtained from the Reefs-Santa Cruz sites, yet on Anuta there was no classic dentate-stamped pottery. What was the relationship between the Anutan plainware and Lapita? We spent a lot of time puzzling over that question. I felt that Golson's use of the 'ceramic series' concept was useful here, in that the Anutan ceramics could be seen as part of a larger Lapitoid series that encompassed plainware traditions as well as the more elaborate dentate-stamped pottery.

I returned to the Pacific again in 1974, spending several months on the islands of Futuna and 'Uvea carrying out an ethnoarchaeological study of traditional ecology and subsistence agriculture for my Yale doctoral project, in the process discovering the first ceramic sites on those islands. With limited resources, I could only excavate at the Tavai (FU-11) site on Futuna, with abundant plainware pottery dating to the late third millennium BP. Once again, the 'Lapitoid series' concept advocated by Golson was useful in placing this ceramic assemblage in a larger framework that saw later plainwares deriving from earlier Eastern Lapita (Kirch 1981). Two years later, I arrived on the northern Tongan island of Niuatoputapu (having intended to return to Futuna, but denied permission by the French authorities, see Kirch 2015:101-102). There I finally had the opportunity to investigate a site (Lolokoka, NT-90) with classic, dentatestamped Lapita pottery. Employing a multi-staged sampling strategy similar to that pioneered by Green, I defined the main area containing decorated pottery at Lolokoka and then opened up a larger excavation. Although the stratigraphy was shallow, and the upper deposits disturbed by generations of gardening (a feature typical of many Lapita sites), we nonetheless recovered a rich array not only of ceramics but of other kinds of portable artefacts (including shell fishhooks), and faunal remains (Kirch 1988).

The excavations at Lolokoka and other Niuatoputapu sites gave me the material to engage with several controversial issues then being debated by archaeologists working on Lapita. The culture-historical issues that had concerned Gifford and Golson were being replaced by new questions, not the least of which was whether the Lapita economy was based largely or even exclusively on marine exploitation ('strandlooping', as proposed by Les Groube (1971)), or had incorporated horticulture and animal husbandry as well. I favoured the latter position, in part because linguistic reconstructions of Proto-Polynesian language included numerous words for crop plants and planting practices. (Having been trained in the holistic, 'four-field' Americanist approach to anthropology, I have always found it useful to incorporate the evidence and insights of historical linguistics.) The recovery of pig bone at Lolokoka was significant, as well as shell scrapers that I argued were used for plant food preparation. But in the 1970s we lacked such methods as microscopic starch grain or phytolith analysis, or of isotopic analysis of bone, that in recent years have revolutionised our ability to reconstruct ancient subsistence practices and diet. Turning to the more abundant faunal evidence for Lapita fishing, Tom Dye and I drew upon our ethnoarchaeological research to argue that on Niuatoputapu, Lapita fishing had employed a range of techniques including netting, spearing and poisoning, which went beyond the angling evidenced by the shell fishhooks we had recovered (Kirch and Dye 1979).

Building on the numerous successes of the first phase of the SSICHP (1970-72), Green and Yen implemented a second phase of the project in 1977-78, again involving field teams from several institutions, this time focusing exclusively on the Santa Cruz and Reef Islands, along with the Polynesian Outliers of Tikopia and Taumako. My main role in the project was an intensive study of Tikopia, carried out over two field seasons in 1977 and 1978, the first together with Doug 
Yen (Kirch and Yen 1982). A long and continuous cultural sequence was revealed, beginning with initial settlement of the island around 2850 BP. The early Kiki site (TK-4) contained small quantities of dentate-stamped Lapita pottery, along with obsidian from the Bismarck Archipelago and other exotic materials indicating initial linkages with the Lapita exchange network. Slightly later sites of the Kiki phase, however, lacked any dentate-stamped pottery, with plainware very much like the Anutan pottery we had excavated in 1971. It was becoming evident that the use of dentate stamping was often a short-lived phenomenon, with ceramic traditions rapidly transforming to plainwares (in some cases with limited rim notching, or some use of incised decoration). This is a pattern that would continue to be evidenced as fieldwork on Lapita sites progressed and radiocarbon dating of early dentate-stamped assemblages was refined, for example in New Caledonia (Sand 2010).

By the late 1970s, thanks in large part though by no means exclusively to the work of the SSICHP, our understanding of Lapita had advanced considerably. The publication of Green's comprehensive synthesis of Lapita in The prehistory of Polynesia volume edited by Jesse Jennings (Green 1979a) marks the end of the culture history phase of Lapita archaeology, dominated by a focus on the pottery. Green explicitly endeavoured 'to compensate for the heavily pottery-based approach by reviewing ... the nonceramic evidence' for Lapita settlements, economy, exchange and non-pottery portable artefacts, redefining Lapita as a cultural complex. He did not, of course, neglect the pottery, drawing upon the formal analysis of Lapita design motifs by Mead et al. (1975) to generate the first statistical evaluation of relatedness among the main Lapita ceramic assemblages then available (Green 1979a: Figure 2.10). Green, who from the beginning of his career had been interested in connections between archaeology and language, also maintained that the Eastern Lapita communities had been speakers of Proto-Central Pacific (1979a:48; see also Pawley and Green 1973). Nonetheless, he was not yet willing to concede Shutler and Marck's bolder proposition that all of Lapita correlates to a higher order subgroup such as Proto-Oceanic (Shutler and Marck 1975).

\section{Debating the Lapita homeland}

The new advances in Lapita archaeology brought with them new debates. In a review article on archaeology in Oceania, Clark and Terrell (1978) directly challenged many of Green's claims regarding the Lapita Cultural Complex, arguing that new kinds of models were called for. Indeed, they urged archaeologists in Oceania to 'abandon writing culture-historical scenarios in favour of more scientific methods of model building, hypothesis testing, and logical presentation' (1978:314). Green did not hesitate to pick up the gauntlet, responding with a thoughtful evaluation of four models, showing that only a 'trader' model withstood the test of empirical evidence (Green 1982). ${ }^{1}$

More contentious was the emerging debate over Lapita origins and the tempo of Lapita expansion across the South-West Pacific, at times couched as a 'fast train to Polynesia' scenario versus an indigenist 'Melanesian origins' scenario. Jim Allen (1984) cogently reviewed these differing positions in a polemic published on the eve of what would prove to be the next major advance in Lapita archaeology: the Lapita Homeland Project.

1 Around 1981-82, Roger Green during a visit to Honolulu gave a seminar in the Anthropology Department at the University of Hawai' $i$ in which he responded to the Clark and Terrell (1978) critique. Sitting in the front row was young Jeff Clark, who had not yet been introduced to Roger. Roger became quite animated as he got into his topic, at one point referring with a subconscious slip of the tongue to 'that article by Clark and Terrible', eliciting quite a laugh from the audience. At the end of the talk Jeff walked up and introduced himself to Roger as 'the Clark of Clark and Terrible'. 
The idea that the Bismarck Archipelago might prove to be the original 'Lapita homeland' stemmed from Roger Green's hypothesis-based on his work on Lapita sites in the Reefs-Santa Cruz Islands - that:

the original Lapita adaptation was to an area with a complex continental island environment, which possessed a wide range of resources that related communities could assemble through exchange. This I place in the New Britain-New Ireland area, from which for 700 years communities far to the east obtained obsidian (1979a:45).

At the 15th Pacific Science Congress in Dunedin, New Zealand, in 1983, Jim Allen assembled a small group of archaeologists (including Green, Golson, Jim Specht, Dimitri Anson, Wallace Ambrose, Peter White and myself) at the James Cook bar, proposing that we collectively undertake a collaborative project to test Green's hypothesis by investigating Lapita in this putative 'homeland' region. Jim intended to explicitly model this new project after the earlier SSICHP, recognising that collaborative, targeted field research was far more effective at addressing major research problems than waiting for individual researchers to gradually assemble the required data sets.

The Lapita Homeland Project (LHP) came to fruition in 1985, with 15 field teams targeting both previously known Lapita sites (such as Watom, and Eloaua in Mussau) and initiating surveys in new areas in Manus, New Ireland, the Duke of York Islands, New Britain and Nissan (Allen and Gosden 1991). The LHP must count as one of the most successful endeavours in the history of Pacific archaeology, resulting not only in the discovery of dozens of new Lapita sites and a wealth of data from their survey, testing and in some cases extensive excavation (Gosden et al. 1989), but also pushing the known temporal depth of human occupation in the Bismarck Archipelago well back into the Pleistocene, with the excavation of several cave sites on New Ireland (Allen et al. 1989).

Jim Allen had asked me to take on the Mussau Islands as my subproject within the LHP, to which I willingly agreed. This was one of the few previously known Lapita localities in the Bismarcks, where Brian Egloff and staff of the Papua New Guinea National Museum had carried out limited excavations on Eloaua Island in 1973 and 1978 (Bafmatuk et al. 1980; Egloff 1975). Although the ECA and ECB sites on Eloaua appeared to be shallow and disturbed by gardening, I hoped that further excavations might be productive. In particular, it was important to confirm whether the time depth for Lapita on Eloaua — indicated by a single radiocarbon date of $3900 \pm 260 \mathrm{cal}$. BP-was accurate, for this was considerably older than any other radiocarbon dates from Lapita sites, and would lend support to the hypothesis that Lapita had undergone a lengthy period of genesis in the Bismarcks. ${ }^{2}$

The LHP expedition ship Dick Smith Explorer dropped Sally Brockwell, Pru Gaffey and me off on Eloaua Island on 1 August, 1985. I have recounted our experiences during that first field season elsewhere (Kirch 2015:190-201), but the events of 11 August are particularly vivid in my memory. We had already dug 13 test pits strung out alongside the small aircraft landing strip on Eloaua (the construction of this airstrip in 1973 had first uncovered the Lapita pottery that attracted Egloff's attention) with little to show for our effort other than a few bags full of small, eroded potsherds. I had decided to place test pit 14 in an area that was about $50 \mathrm{~cm}$ lower in elevation than the old beach ridge where we had been digging, to test my hypothesis that this was the original reef flat at the time of Lapita occupation, prior to a later drop in sea level and consequent progradation of the shoreline. When Gaffey, who was digging into the soft calcareous sands just at the upper limit of the Ghyben-Herzberg aquifer, called for me to come and see

2 The additional ${ }^{14} \mathrm{C}$ dates we obtained in our 1985 excavations at ECA showed this early date of Egloff's to be aberrant, with Lapita occupation in Mussau not beginning earlier than 3500-3400 BP. 
what she was uncovering, I was astounded. Gaffey pointed to several large, well-decorated Lapita sherds, one with a human face motif clearly visible. More trowelling turned up a complete Tridacna shell ring, obsidian flakes, a drilled pig tusk and more sherds. As we continued down into the now waterlogged sands, a circular, black organic stain appeared, gradually revealing itself as a well-preserved wooden post base.

It would take several more weeks of excavation, with test pit 14 expanded into a 12 -squaremetre excavation, before we were fully confident of what we had discovered-the anaerobically preserved post along with several others that were exposed in the expanded excavation were the remains of stilts that had once supported a house standing over the shallow reef flat. This was the first indication that Lapita settlements had incorporated over-water stilt houses (a discovery reinforced by Gosden's work in the Arawe Islands), a significant insight with implications for archaeological survey and site visibility. The Area B excavation at ECA (or Talepakemalai, as the site is known to the Eloaua people) was furthermore extremely rich not only in elaborately decorated pottery (including a variety of vessel forms), but also in non-ceramic portable artefacts such as shell rings, pendants and fishhooks, as well as abundant faunal remains (particularly fishbones and molluscs). To top things off, the site's anaerobic conditions preserved not only the wooden post bases, but hundreds of other organic remains including the seeds of a number of species of tree crops (coconut, Canarium almond, Terminalia and many others). ${ }^{3}$

Before I even left Eloaua at the end of the 1985 season, I knew that I would have to return. After securing additional research funds, I carried out two more field seasons in Mussau, in 1986 and 1988, in the end digging more than 84 square metres at ECA, and sampling several other sites on Emananus, Boliu, Emussau and 'Big Mussau' islands (Kirch 2001). The Mussau project has been the core of my personal engagement with Lapita, and 30 years after I closed up the last test pit, I am still finishing my analysis of the extensive materials we obtained. A long-promised final monograph, including the description and illustration of more than 250 reconstructed pottery vessels, is slated for publication next year.

Drawing extensively on the materials from ECA and other sites in Mussau, along with other results of the LHP and previous projects in the Solomons, New Caledonia, Fiji and Tonga, I attempted a book-length synthesis in The Lapita peoples (Kirch 1997). My subtitle, Ancestors of the Oceanic world, was carefully chosen, reflecting my view that not only were the Lapita people the first to voyage beyond the Solomon Islands into what Roger Green (1991a) had by then labelled 'Remote Oceania', but that Lapita could be correlated with the Oceanic branch of Austronesian languages. As I wrote:

the correlation of the early Lapita phase with Proto Oceanic, and of the subsequent Lapita dispersal with the spread and later the break-up of the Proto Oceanic speech community is ... the only explanation which makes consistent sense of both the linguistic and archaeological evidence amassed to date (Kirch 1997:89).

I went on to review the newly developing biological evidence for a 'genetic trail' (Hill and Serjeantson 1989) that also supported the hypothesis of a 'demic' or population intrusion into Near Oceania from island Southeast Asia. I observed that:

what is most gratifying about the recent genetic studies of Pacific peoples is the strong convergence between the scenario indicated by genetics, and that reconstructed by the historical linguists. These two fields-working with wholly independent data sets-have produced historical narratives both requiring a relatively recent intrusion of people into the long-settled region of Near Oceania (Kirch 1997:107).

3 That the 1985 Mussau finds were stunning is confirmed by Matthew Spriggs, who writes that '[Kirch] was able to snaffle up the jewel in the crown of sites that were investigated [by the LHP] with his work on Eloaua ... Other project members were insane with jealousy' (Spriggs 2017:137). 
Two decades later, the tremendous advances in sequencing ancient DNA (e.g. Skoglund et al. 2016) now reinforce that conclusion ever more strongly.

While for me the evidence from archaeology, human genetics and historical linguistics all combined to demonstrate that the Lapita phenomenon in Near Oceania involved the arrival of a new group of Austronesian-speaking (Oceanic) people, it was equally evident that interaction with the pre-existing Papuan occupants of the Bismarcks had played a role in the emergence of a distinct Lapita culture during the final centuries of the fourth millennium BP. Roger Green (1991b) had come to the same conclusion, putting forward his now well-known 'Triple I' model of Lapita, with its three components of intrusion, innovation and integration. In The Lapita peoples, I chose a more literary way of advancing the same idea, adopting Greg Dening's metaphor of 'the beach', that threshold across which intrusive newcomers meet indigenous communities, exchanging words, ideas and genes (Dening 2004). In short, one key outcome of the LHP was a rejection of both the 'fast train to Polynesia' and the 'indigenous Melanesian origins' of Lapita models, and their replacement with an understanding that Lapita was the result of 'sustained encounters between immigrant and indigenous peoples out of which a new cultural synthesis emerged' (Kirch 1997:46).

\section{The Lapita expansion in Remote Oceania}

My own field engagement with Lapita ended with the 1988 Mussau expedition, my research becoming reoriented to Eastern Polynesia. Since 1988, I have been more of a bystander and observer of others' continued efforts to wrest new Lapita finds from island sands, while of course continuing to intermittently work with the large assemblage of pottery and other finds from Mussau that filled my laboratory shelves. During this time, some research has continued on Lapita in the Near Oceanic area (e.g. Summerhayes 2007); however, much of the newer fieldwork has focused on Remote Oceania, leading to important new discoveries that have filled in a number of previous gaps in Lapita geographic distribution, and led to improved information on the timing of the Lapita expansion and the chronology of Lapita transformations across the south-western Pacific.

The timing of the initial Lapita movement from Near Oceania into the Reefs-Santa Cruz Islands-presumably the first group in Remote Oceania to be settled in the expansion eastwards out from the Bismarck-Solomons chain-has been tied down to about 3100-3000 cal. BP. (Sheppard et al. 2015), somewhat younger than Green originally estimated. Since the date for initial onset of Lapita in the Bismarcks has also gotten younger (Specht and Gosden this volume), that means that the elapsed time for Far Western Lapita development prior to the expansion eastwards has also shortened, to two centuries or perhaps less. ${ }^{4}$ The nagging question of the central Solomons (Bougainville to Makira) remains unanswered: is the absence of Lapita sites in this large region simply a consequence of the very limited amount of archaeological fieldwork to date, or does it indicate, as Sheppard (2011) argues, that Lapita colonists 'leap-frogged' over the central Solomons? To me, this remains an open question, with the evidence equivocal or consistent with multiple models. I would love to see a coordinated international project tackle the central Solomons, in the same way that the SSICHP and LHP did for the Eastern Solomons and the Bismarcks, respectively-I have no doubt the gain in knowledge would be remarkable.

4 I recently obtained a new suite of AMS dates on short-lived materials such as Canarium nut seed cases from ECA and other Mussau sites. These dates, which will be published in the final site monograph, indicate a somewhat younger date for initial Lapita in Mussau than I had previously reported based on the radiocarbon dates obtained in the 1980s (Kirch 2001). 
In Vanuatu, the past two decades have witnessed the addition of a number of Lapita sites to the known inventory for this archipelago, such as Vao and Makué, but none has been more significant than Teouma on Efate Island (Bedford 2007; Bedford et al. 2006), a site that rivals Talepakemalai (ECA) in Mussau in the rich diversity of ceramic vessels. Unlike ECA, however, Teouma included a cemetery with the pots being used as containers or covers for inhumations. This direct material association of dentate-stamped pottery (many vessels displaying human face motifs) with ancestral remains provides further support for the idea that ceramics played key social and ritual roles in Lapita culture (Kirch 1997:152-153, 188-191). Equally important, the skeletal remains themselves have been the focus of several kinds of analysis, including morphometrics (Valentin et al. 2016) and aDNA amplification and sequencing (Skoglund et al. 2016), both of which point to an Island Southeast Asian and/or Taiwanic genetic affinity for the initial population of Lapita colonists, with little or no gene flow between them and the indigenous ('Papuan') populations already resident in New Guinea and the Bismarcks.

Other archipelagos have also seen their inventories of classic Lapita sites (i.e. by definition those with pottery bearing the characteristic dentate-stamped designs) increase, including the Loyalties and New Caledonia (Sand 2010), Fiji (Clark and Anderson 2009) and Tonga (Burley et al. 2015). And in all of these islands, the time span for classic Lapita has been compressed, to between no earlier than c. 3050 BP for first arrivals and with the dentate-stamped phase itself typically ending by $2700 \mathrm{BP}$ or even slightly earlier. Older claims for Lapita persisting into much younger time periods can now be dismissed as being based on erroneous dates. This means that the Lapita expansion across a large swatch of the south-western Pacific occurred very rapidly indeed.

A final observation I might make, from the sidelines of watching Lapita studies develop among my colleagues and their students over the past few decades, is that there has been a gradual shift from an emphasis on fieldwork, especially extensive excavation, to the application of new techniques and approaches (isotopic analyses, aDNA, X-ray fluorescence (XRF) sourcing, to name a few) either to existing collections, or to materials obtained through limited test pits. There have, of course, been a handful of new extensive excavations (Teouma for one, and Nukuleka in Tonga), but I sense a movement nonetheless toward more restricted digging and more extensive reanalysis of legacy collections. To some extent this is probably a good thing, although some questions (such as the problem of the central Solomons) are only going to be answered through more fieldwork. It is also worth pointing out that rising global sea levels (due to global greenhouse warming) are predicted to accelerate rates of coastal erosion, and many Lapita sites either are or will soon become endangered; excavation may be the only way to preserve their contents.

\section{Lapita studies now and into the future}

From the perspective of one who has watched the field of Lapita studies change over five decades - and participated directly in some of those changes - where have we arrived, and where might the field be headed in the future? The presentations at the Vanuatu Lapita conference and the resulting papers in this volume provide a stimulating sampling of current research directions. To conclude this essay, I offer a few comments on the following enduring issues in Lapita archaeology: the distribution and geographic limits of Lapita; chronology; ceramics in the context of exchange systems and social organisation; and the Lapita economy.

A significant addition to our understanding of the geographic extent of Lapita has been the discovery of occupations with a late form of dentate-stamped Lapita at Caution Bay, along the Papuan coast (Bruno et al. this volume), a not-unexpected finding given that sites such as Oposisi and Nebira 4 had been interpreted as derivative from an earlier Lapita tradition 
(Kirch 2000:122). I also predicted some years ago-and would still maintain—that 'further fieldwork along the north-eastern Papuan coast and/or in the Massim Islands may ultimately yield Lapita occupations' (2000:122). Despite some survey work, the Massim remains largely unexplored from an archaeological perspective, and I would urge some among the next generation of Pacific archaeologists to undertake new fieldwork in these potentially significant islands. And, as I mentioned earlier, the central and eastern Solomon Islands likewise remain a huge lacuna in our knowledge; renewed and intensive fieldwork on these islands is, in my view, essential to testing the 'leapfrog hypothesis' of apparent Lapita absence in the region (Sheppard this volume). At the other end of the Lapita distribution, in Samoa, we still have just the single, submerged site of Mulifanua in that large island group. Although claims have been made that limited coastal land restricted Lapita colonisation in Samoa (Cochrane et al. 2015), I am doubtful of this explanation, as limited land certainly did not halt Lapita settlement in other island groups. My view is that in Samoa the problem is one of archaeological site visibility, due to rapid submergence and dynamic coastal geomorphology; new methods of subsurface survey in the coastal interface may in time resolve the issue.

Turning to chronology, we have come a very long way from the picture 30 or more years ago, eliminating outlying dates on both the old and young extremes, and bracketing the period of classic dentate-stamped pottery to a relatively short duration of about three to four centuries. Nonetheless, issues remain, especially with respect to the chronology of Far Western Lapita in the Bismarck Archipelago, as Specht and Gosden (this volume) aver. The uncertainties derive in large part from extensive radiocarbon dating of marine shell at sites such as Talepakemalai (Kirch 2001), where charcoal was scarce or absent, with the shell dates having unknown variations in marine reservoir offsets. Based on new dates from the Arawe Island sites, Specht and Gosden now suggest that Far Western Lapita may not begin until c. 3250-3150 BP, quite a lot younger than the 3550-3450 BP suggested at the conclusion of the LHP. I can report here that a series of 20 new accelerator mass spectrometry (AMS) radiocarbon dates that I recently obtained on short-lived, anaerobically preserved plant remains (Canarium nut shell, coconut, wood) from the ECA, ECB and EHB sites in Mussau agree quite well with Specht and Gosden's new estimate of around 3250 BP. I expect to publish these new dates in full, including a Bayesian analysis of the Mussau chronology, in the near future.

A major advance in archaeological chronology in the Pacific has come in recent years with the application of ${ }^{230} \mathrm{Th}$ dating of corals. Burley et al. (2015) applied this method to branch coral abraders from the Nukuleka site on Tongatapu to precisely date Lapita colonisation. My own recent and ongoing collaboration with geochronologist Warren Sharp has shown that coral abraders in Eastern Polynesian sites can provide highly reliable chronologies that correlate well with AMS radiocarbon dates but are more precise (Niespolo et al. 2019). A program of ${ }^{230} \mathrm{Th}$ dating of coral abraders from previously excavated Lapita sites, now curated in museum collections, could help to further refine the chronology of Lapita expansion across the south-western Pacific.

Not surprisingly, the intricately decorated Lapita pottery continues to be a major focus of current investigations, as several chapters in this volume attest (by Ambrose, Bedford, Chiu, LeBlanc et al., Noury, and Spriggs). Roger Green in a seminal paper argued that Lapita art was of the pervasive type (as opposed to partitive), in which the same motifs and rules of design apply across different media such as pottery, barkcloth, wood carving and tattooing (Green 1979b). Following on this notion, I argued that there was a close relationship between tattooing and dentate-stamped decoration (Kirch 1997:142-143, 152), with the vessels themselves in many instances representing tattooed ancestors (especially those vessels with face motifs). Ambrose (this volume) outlines a case for some of the motifs on Lapita pottery being transferred from 
plaited textile designs to ceramics. This is quite plausible, especially for some of the intricate 'labyrinth' and 'zigzag' motifs that occur with high frequency on Far Western Lapita vessels, as in Mussau. Spriggs (this volume) further explores the possible meaning and significance of the anthropomorphic designs that occur with high frequency in Far Western and Western Lapita assemblages. Drawing on the discovery that human crania were a focus on Lapita burial rites at Teouma, Spriggs suggests that the depictions on Lapita vessels may be more about ancestral 'heads' than 'faces'.

A major effort over the past decade or so by Scarlett Chiu and colleagues in Taiwan has been the construction of the Lapita Pottery On-line Database (LPOD), which now contains an abundance of data on pottery assemblages from some 50 Lapita sites. In her chapter, Chiu presents some preliminary results of an analysis of motif diversity and shared motifs among Lapita sites, a leap forward from the tentative statistical analysis first attempted by Green (1979a). As more site assemblages are coded and entered into the LPOD in future years, our ability to carry out sophisticated comparisons between Lapita sites across the south-west Pacific will continue to improve, no doubt bringing additional insights. Lapita archaeologists are indebted to Chiu for leading the way in this huge project.

Finally, turning to the topic of Lapita economy and subsistence, something that I was especially concerned with in my earlier work on Eastern Lapita in Futuna and Niuatoputapu, and later in Mussau, it is evident that the old debates about whether the Lapita economy was based on 'strandlooping' or included a horticultural component can now be put to rest. Both the macroscopic finds of plant remains at sites such as Mussau and the Arawe Islands, and the independent testimony of historical linguistics (with a rich Proto-Oceanic vocabulary of words for crop plants and for planting practices (Kirch 1997: Tables 7.2 and 7.3)), have now been augmented by the evidence from new methods such as the extraction of starch grains and phytoliths from the dental calculus of Lapita teeth (Tromp 2016). Stable isotope analysis of Lapita skeletal remains from Teouma (Kinaston et al. 2014) have likewise provided new perspectives on Lapita diet. The accumulated evidence from all of these sources leaves no doubt that the Lapita colonisers of Remote Oceania not only exploited the natural terrestrial and marine resources of the islands (in some cases leading to rapid extinction of vulnerable species, such as megapodes and horned tortoises), but transferred with them the crops and horticultural practices that would in time provide the basis for intensive food production systems.

To conclude, my personal engagement with Lapita over these past five decades has been an exhilarating journey-both literally in terms of fieldwork across various Pacific islands, and intellectually in the ongoing debates with colleagues and students regarding the significance of Lapita in Oceanic prehistory. Our advances in knowledge over these 50 years have been huge, fostered in part by continued improvements in archaeological methods and analytical techniques, but also by the hard fieldwork of discovering and excavating Lapita sites across dozens of islands. But there is still so much more to do and to learn. My generation has stood on the shoulders of the pioneers of Lapita archaeology, Gifford, Golson and Green, to arrive at our current state of knowledge, and we owe them a great debt of gratitude.

\section{References}

Allen, J. 1984. In search of the Lapita homeland. Journal of Pacific History 19:186-201. doi.org/10.1080/ 00223348408572494.

Allen, J. and C. Gosden (eds) 1991. Report of the Lapita Homeland Project. Occasional Papers in Prehistory No 20. Department of Prehistory, RSPacS, The Australian National University, Canberra. 
Allen, J., C. Gosden and J.P. White 1989. Human Pleistocene adaptations in the tropical island Pacific. Antiquity 63:548-561. doi.org/10.1017/S0003598X00076547.

Ambrose, W.R. and R.C. Green 1972. First millennium BC transport of obsidian from New Britain to the Solomon Islands. Nature 237:31. doi.org/10.1038/237031a0.

Bafmatuk, R., B. Egloff and R. Kaiku 1980. Islanders: Past and present. Hemisphere 25:77-81.

Bedford, S. 2007. Crucial first steps into Remote Oceania: Lapita in the Vanuatu archipelago. In S. Chiu and C. Sand (eds), From Southeast Asia to the Pacific: Archaeological perspectives on the Austronesian expansion and the Lapita Cultural Complex, pp. 185-213. Centre for Archaeological Studies, Research Centre of Humanities and Social Sciences. Academia Sinica, Taipei.

Bedford, S., M. Spriggs and R. Regenvanu 2006. The Teouma Lapita site and the early human settlement of the Pacific Islands. Antiquity 80(310):812-828. doi.org/10.1017/S0003598X00094448.

Burley, D., K. Edinborough, M. Weisler and J.-x. Zhao 2015. Bayesian modeling and chronological precision for Polynesian settlement of Tonga. PLoS ONE 10:e0120795. doi.org/10.1371/journal. pone.0120795.

Clark, G. and A. Anderson (eds) 2009. The early prehistory of Fiji. Terra Australis 31. ANU E Press, Canberra. doi.org/10.22459/TA31.12.2009.

Clark, J.T. and J. Terrell 1978. Archaeology in Oceania. Annual Review of Anthropology 7:293-319. doi.org/10.1146/annurev.an.07.100178.001453.

Cochrane, E.E., H. Kane, C. Fletcher III, M. Horrocks, J. Mills, M. Barbee, A.E. Morrison and M.M. Tautunu 2015. Lack of suitable coastal plains likely influenced Lapita $(-2800 \mathrm{cal}$. BP) settlement of Samoa: Evidence from south-eastern 'Upolu. The Holocene 26:126-135. doi.org/10.1177/09596 83615596841.

Dening, G. 2004. Beach crossings: Voyaging across times, cultures and self. Miegunyah Press, Melbourne.

Egloff, B.J. 1975. Archaeological investigations in the coastal Madang area and on Eloaue Island of the St. Matthias Group. Records of the Papua New Guinea Public Museum and Art Gallery 5:15-31.

Gifford, E.W. and D. Shutler Jr 1956. Archaeological excavations in New Caledonia. Anthropological Records 18(1). University of California Press, Berkeley and Los Angeles.

Golson, J. 1961. Report on New Zealand, Western Polynesia, New Caledonia, and Fiji. Asian Perspectives 5:166-180.

Golson, J. 1971. Lapita ware and its transformations. In R.C. Green and M. Kelly (eds), Studies in Oceanic culture history, Volume 2, pp. 67-76. Pacific Anthropological Records 12. Bernice P. Bishop Museum, Honolulu.

Gosden, C., J. Allen, W. Ambrose, D. Anson, J. Golson, R. Green, P. Kirch, I. Lilley, J. Specht and M. Spriggs 1989. Lapita sites of the Bismarck Archipelago. Antiquity 63:561-586. doi.org/10.1017/ S0003598X00076559.

Green, R.C. 1967. The immediate origins of the Polynesians. In G.A. Highland, R.W. Force, A. Howard, M. Kelly and Y.H. Sinoto (eds), Polynesian culture history, pp. 215-240. Bishop Museum Press, Honolulu.

Green, R.C. 1976. Lapita sites in the Santa Cruz group. In R.C. Green and M.M. Cresswell (eds), Southeast Solomon Islands cultural history: A preliminary survey, pp. 245-265. Royal Society of New Zealand Bulletin 11. Royal Society of New Zealand, Wellington.

Green, R.C. 1979a. Lapita. In J.D. Jennings (ed.), The prehistory of Polynesia, pp. 27-60. Harvard University Press, Cambridge, Mass. doi.org/10.4159/harvard.9780674181267.c3. 
Green, R.C. 1979b. Early Lapita art from Polynesia and Island Melanesia: Continuities in ceramic, barkcloth, and tattoo decorations. In S.M. Mead (ed.), Exploring the visual art of Oceania, pp. 13-31. University of Hawai'i Press, Honolulu.

Green, R.C. 1982. Models for the Lapita Cultural Complex: An evaluation of some current proposals. New Zealand Journal of Archaeology 4:7-19.

Green, R.C. 1991a. Near and Remote Oceania: Disestablishing 'Melanesia' in culture history. In A. Pawley (ed.), Man and a half: Essays in Pacific anthropology and ethnobiology in honour of Ralph Bulmer, pp. 491-502. The Polynesian Society, Auckland.

Green, R.C. 1991b. The Lapita Cultural Complex: Current evidence and proposed models. In P. Bellwood (ed.), Indo-Pacific prehistory 1990: Proceedings of the 14th Congress of the Indo-Pacific Prehistory Association, pp. 295-305. Indo-Pacific Prehistory Association, Canberra.

Green, R.C. and M.M. Cresswell (eds) 1976. Southeast Solomon Islands cultural history: A preliminary survey. Royal Society of New Zealand Bulletin 11. Royal Society of New Zealand, Wellington.

Groube, L. 1971. Tonga, Lapita pottery and Polynesian origins. Journal of the Polynesian Society 80:278316.

Hill, A.V.S. and S.W. Serjeantson (eds) 1989. The colonization of the Pacific: A genetic trail. Clarendon Press, Oxford.

Kinaston, R., H. Buckley, F. Valentin, S. Bedford, M. Spriggs, S. Hawkins and E. Herrscher 2014. Lapita diet in Remote Oceania: New stable isotope evidence from the 3000-year-old Teouma site, Efate Island, Vanuatu. PLoS ONE 9(3):e90376. doi.org/10.1371/journal.pone.0090376.

Kirch, P.V. 1981. Lapitoid settlements of Futuna and Alofi, Western Polynesia. Archaeology in Oceania 16:127-143. doi.org/10.1002/j.1834-4453.1981.tb00023.x.

Kirch, P.V. 1988. Niuatoputapu: The prehistory of a Polynesian chiefdom. Thomas Burke Memorial Washington State Museum Monograph 5. Burke Museum, Seattle.

Kirch, P.V. 1997. The Lapita peoples: Ancestors of the Oceanic world. Blackwell, Oxford.

Kirch, P.V. 2000. On the road of the winds: An archaeological history of the Pacific Islands before European contact. University of California Press, Berkeley.

Kirch, P.V. (ed.) 2001. Lapita and its transformations in Near Oceania: Archaeological investigations in the Mussau Islands, Papua New Guinea, 1985-88. Volume I: Introduction, stratigraphy, chronology. Archaeological Research Facility Contribution No. 59. University of California, Berkeley.

Kirch, P.V. 2015. Unearthing the Polynesian past: Explorations and adventures of an island archaeologist. University of Hawai'i Press, Honolulu. doi.org/10.21313/hawaii/9780824853457.001.0001.

Kirch, P.V. and T.S. Dye 1979. Ethno-archaeology and the development of Polynesian fishing strategies. Journal of the Polynesian Society 88:53-76.

Kirch, P.V. and P.H. Rosendahl 1973. Archaeological investigations of Anuta. In D.E. Yen and J. Gordon (eds), Anuta: A Polynesian Outlier in the Solomon Islands, pp. 25-108. Pacific Anthropological Records 21. Bernice P. Bishop Museum, Honolulu.

Kirch, P.V. and D.E. Yen 1982. Tikopia: The prehistory and ecology of a Polynesian Outlier. Bernice P. Bishop Museum Bulletin 238. Bishop Museum Press, Honolulu.

Mead, S.M., L. Birks, H. Birks and E. Shaw 1975. The Lapita pottery style of Fiji and its associations. Polynesian Society Memoir No. 38. Polynesian Society, Wellington. 
Niespolo, E., W.D. Sharp and P.V. Kirch 2019. ${ }^{230}$ Th dating of coral abraders from stratified deposits at Tangatatau Rockshelter, Mangaia, Cook Islands: Implications for building precise chronologies in Polynesia. Journal of Archaeological Science 101:21-33. doi.org/10.1016/j.jas.2018.11.001.

Pawley, A. and R.C. Green 1973. Dating the dispersal of the Oceanic languages. Oceanic Linguistics 12:1-67. doi.org/10.2307/3622852.

Sand, C. 2010. Lapita Calédonien: Archéologie d'un premier peuplement Insulaire Océanien. Société des Océanistes, Paris. doi.org/10.4000/books.sdo.1128.

Sheppard, P.J. 2011. Lapita colonization across the Near/Remote Oceania boundary. Current Anthropology 52(6):799-840. doi.org/10.1086/662201.

Sheppard, P.J. and R.C. Green 1991. Spatial analysis of the Nenumbo (SE-RF-2) Lapita site, Solomon Islands. Archaeology in Oceania 26:89-101. doi.org/10.1002/j.1834-4453.1991.tb00272.x.

Sheppard, P.J., S. Chiu and R. Walter 2015. Re-dating Lapita movement into Remote Oceania. Journal of Pacific Archaeology 6(1):26-36.

Shutler, R., Jr. and J.C. Marck 1975. On the dispersal of the Austronesian horticulturalists. Archaeology and Physical Anthropology in Oceania 10:81-113.

Skoglund, P., C. Posth, K. Sirak, M. Spriggs, F. Valentin, S. Bedford, G. Clark, C. Reepmeyer, F. Petchey, D. Fernandes, Q. Fu, E. Harney, M. Lipson, S. Mallick, M. Novak, N. Rohland, K. Stewardson, S. Abdullah, M. Cox, F. Friedlaender, J. Friedlaender, T. Kivisild, G. Koki, P. Kusuma, A. Merriwether, F.-X. Ricaut, J. Wee, N. Patterson, J. Krause, R. Pinhasi and D. Reich 2016. Genomic insights into the peopling of the Southwest Pacific. Nature 538(7626):510-513 and Supplementary Information. doi.org/10.1038/nature19844.

Spriggs, M. 2017. Review of P.V. Kirch, Unearthing the Polynesian past. Archaeology in Oceania 52:135138. doi.org/10.1002/arco.5127.

Summerhayes, G.R. 2007. The rise and transformation of Lapita in the Bismarck Archipelago. In S. Chiu and C. Sand (eds), From Southeast Asia to the Pacific: Archaeological perspectives on the Austronesian expansion and the Lapita Cultural Complex, pp. 141-169. Centre for Archaeological Studies, Research Centre of Humanities and Social Sciences. Academia Sinica, Taipei.

Tromp, M. 2016. Lapita plants, people and pigs. Unpublished PhD thesis, University of Otago, Dunedin.

Valentin, F., F. Detroit, M. Spriggs and S. Bedford 2016. Early Lapita skeletons from Vanuatu show Polynesian craniofacial shape: Implications for Remote Oceanic settlement and Lapita origins. Proceedings of the National Academy of Sciences 113:292-297. doi.org/10.1073/pnas.1516186113. 
This text is taken from Debating Lapita: Distribution, Chronology, Society and Subsistence, edited by Stuart Bedford and Matthew Spriggs, published 2019 by ANU Press,

The Australian National University, Canberra, Australia.

doi.org/10.22459/TA52.2019.23 